\title{
EFFECTIVENESS OF THE BRAZILIAN INFLUENZA VACCINATION POLICY, A SYSTEMATIC REVIEW
}

\author{
Expedito J.A. LUNA(1) \& Vera L. GATTÁS(2)
}

\begin{abstract}
SUMMARY
Since 1999, Brazil has undertaken annual influenza vaccine campaigns, free of charge, targeting the elderly population, health professionals, and immune-deficient patients. We conducted a systematic review of literature in order to evaluate the effectiveness of the initiative. We used the keywords influenza, vaccine, Brazil and effectiveness to search the main databases. Thirty-one studies matched our inclusion and exclusion criteria. Influenza vaccine coverage among the elderly is high, though not as high as suggested by the official figures. Estimates on effectiveness are scarce. The majority come from ecological studies that show a modest reduction in mortality and hospital admissions due to influenza-related causes. Such reduction is not evident in the North and Northeastern states of Brazil, a finding that is probably related to the different seasonal pattern of influenza in equatorial and tropical regions. Brazilian epidemiologists still owe society better-designed studies addressing the effectiveness of influenza vaccine campaigns.
\end{abstract}

KEYWORDS: Influenza; Brazil; Vaccines; Effectiveness.

\section{INTRODUCTION}

Since 1999, Brazil undertakes annual influenza vaccine campaigns targeting the elderly population, other groups vulnerable to influenza complications, and health professionals. The flu vaccine has been provided, free of charge, in national campaigns, which usually have been held in late April/ early May. In 1999, the campaign targeted the population over 65 years of age. Since 2000 it has targeted the population over 60 . Influenza vaccination campaigns have been regarded as largely successful, reaching high vaccine coverage (Fig. 1) among the elderly, the largest group included in the initiative.

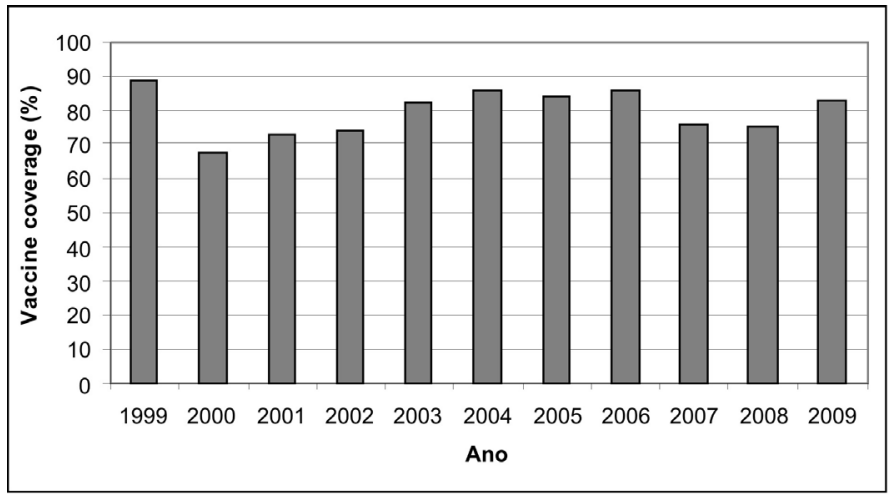

Source: CGPNI/DEVEP/SVS/MS.

* In 1999, vaccination was administered to the population > 65 y. (Updated in 09/16/2009).

Fig. 1 - Influenza Vaccine coverage among the population > 60 years of age, Brazil - 1999 to 2009 .*
According to the Ministry of Health (MOH) figures, coverage has reached the $70 \%$ target among the elderly population in all years, except 2000. MOH does not present figures on vaccine coverage in other groups targeted in the flu vaccine campaigns (health care workers, transplant patients, people living with immune deficiencies, and other groups of high risk patients for influenza complications), because of the alleged lack of denominators for the coverage calculus.

In spite of such apparent success, little is known about the effectiveness of the initiative. We have conducted a systematic review regarding the effectiveness of the Brazilian influenza vaccine, in order to clarify what has already been established on the subject, and what remains to be understood.

\section{METHODS}

We conducted a systematic review of literature on influenza vaccine effectiveness studies in Brazil, using the keywords influenza, Brazil, vaccine, and effectiveness in different combinations. We searched in Medline, PubMed, Lilacs, BVS and Scielo, with no restriction on publication dates. We used as inclusion criteria any study that analyzed the Brazilian influenza vaccine policy. As exclusion criteria: any study published before 1999, clinical trials carried out in Brazil, evaluation of influenza vaccine in occupational settings outside the Brazilian policy, outbreak investigations, and papers on laboratory methods. The searches were done between September 2009 and May 2010. By systematically reviewing published data, we aim to provide better estimates of influenza vaccination effectiveness in Brazil and the factors related to it. The

(1) Instituto de Medicina Tropical de São Paulo, Universidade de São Paulo. São Paulo, SP, Brasil.

(2) Instituto Butantan, São Paulo, SP, Brasil.

Correspondence to: Expedito J.A. Luna, Instituto de Medicina Tropical de São Paulo, Av. Dr. Enéas de Carvalho Aguiar 470, 05403-000 São Paulo, SP, Brasil. E-mail: eluna@usp.br 
recovered articles were first selected on the basis of publication year: the Brazilian vaccination policy was introduced in 1999, so papers published before that year could not have evaluated it. After we analyzed their titles to confirm they were related to the issues of interest, and later, their abstracts were analyzed, to reassure that they addressed the effectiveness of the Brazilian vaccination policy or any factors related to it. Once the articles were selected, we reviewed their reference lists, in order to find other articles that might have been missed in our databases search. In this latter step, we have also included some unpublished papers that were considered relevant, such as academic studies (dissertations, theses) and reports from public health authorities.

\section{RESULTS}

We found 380 articles that matched our search criteria. We then analyzed the list, excluding the ones that were published before the beginning of the Brazilian influenza vaccination campaigns (1999), those that were not actually related to Brazil (some referred to the Brazil influenza B viral subtype), and a few others that did not address the issues of interest (Fig. 2). 51 papers were selected as potentially relevant.

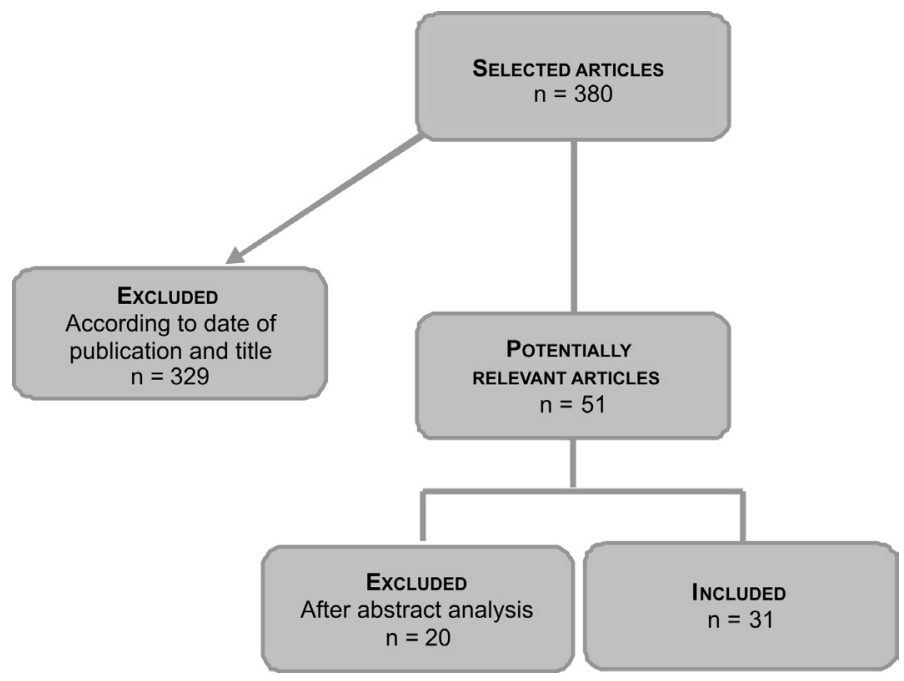

Fig. 2 - Systematic review flowchart.

We then re-analyzed these papers' abstracts, to ensure they addressed the issue of interest, and when necessary, the whole article was analyzed. 20 more articles were excluded. Elimination was based on the exclusion criteria, and the evaluation of the issues actually covered by the abstracts and articles. For instance, some of the excluded papers were reports of clinical trial results of new influenza vaccines, conducted in Brazil; some others addressed vaccine effectiveness in occupational settings not covered by the national policy; some presented outbreak investigations, or either laboratorial diagnosis. Some unpublished studies $(n=3)$ were found during the analysis of the selected papers' lists of references. Eventually, 31 papers were selected. Selected articles were then classified in 5 categories (Fig. 3):

1) Articles that presented data on influenza vaccine coverage.

2) Articles addressing the seasonality of influenza in Brazil.

3) Articles on vaccine effectiveness, using an ecological approach.

4) Articles on vaccine effectiveness with individual based study designs.

5) Review articles.

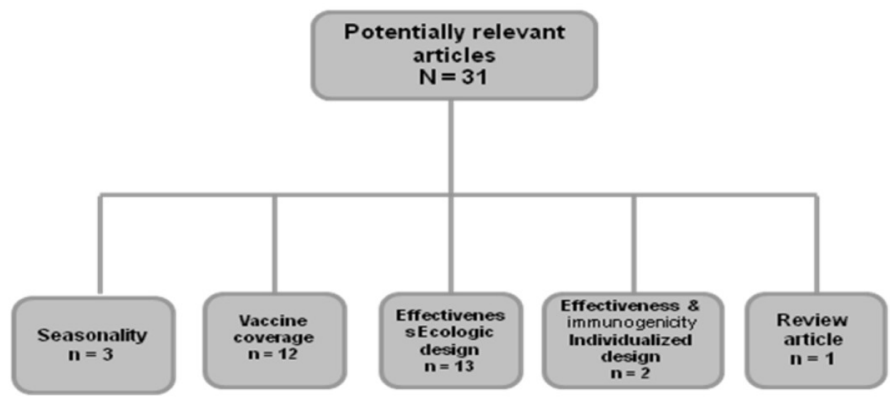

Fig. 3 - Syatematic review results.

Vaccine coverage: fourteen studies presented survey data on vaccine coverage. Among them, four evaluated vaccine coverage among health professionals and/or immune-deficient patients (Table 1). Among health professionals, two surveys conducted in two of the leading university hospitals in the country presented coverage of $19.7 \%$ and $34.4 \%{ }^{4,33}$. In the same institutions, vaccine coverage among transplant patients varied between $44.2 \%$ (bone marrow transplant) and 0\% (kidney) ${ }^{5,25}$. The other ten studies analyzed vaccine coverage among the senior population. The majority of them were surveys conducted in representative samples of the target population, ${ }^{7,9,13,16,17,20,24}$ and the remaining three among outpatients of a primary care clinic and reference hospitals ${ }^{22,23,30}$. Five surveys detected vaccine coverage similar to the Ministry of Health's (MOH) administrative data $a^{9,13,16,17,30}$. On the other hand, large differences were observed by the other three: among the elderly of two low income communities ("favelas") in the city of Rio de Janeiro, survey coverage was $50.2 \%$ and $38.3 \%$, compared to $\mathrm{MOH} 75.7 \%$ coverage for the whole city; $66.3 \%$ coverage in Belo Horizonte, the country's third largest city, compared to $85.5 \%$ according to $\mathrm{MOH}$ data; and $83.8 \%$ among outpatients of a primary care clinic in Botucatu, state of São Paulo, compared to $62.2 \%(\mathrm{MOH})^{7,22,24}$.

Ecologic studies: Thirteen of the recovered studies evaluated the Brazilian vaccine strategy effectiveness using an ecological design. Three additional studies used the same design to address influenza seasonality in Brazil. Table 2 presents a summary of these studies. Seven studies analyzed mortality data time series, ${ }^{2,3,8,12,18,21,26}$ while five analyzed hospital admissions data ${ }^{6,11,15,19,31}$. One study used both mortality and morbidity data ${ }^{14}$. Two others analyzed time series of laboratory-confirmed influenza cases to discuss seasonality ${ }^{27,28}$. Mortality studies have been used as outcomes to influenza-related death causes, which usually include influenza, pneumonia and obstructive respiratory diseases. Their analysis included different time series, and also different geographic units (the whole country, a state, a municipality), and comparison of pre- and post-vaccination mortality rates were made using different time frames. Some studies found a decrease in influenza-related mortality, while some others found the opposite trend. A decrease in influenza-related mortality was more evident in Southern states, and even the studies that found an overall increase in rates showed a reduction in peaks of mortality after the introduction of mass vaccine campaigns, a phenomenon that was more pronounced in Southern states. One study analyzed the effect of influenza vaccination upon mortality due to ischemic heart disease (IHD). The study found a significant reduction of IHD mortality after the introduction of the mass vaccination of the elderly ${ }^{26}$. Influenza morbidity studies have used data from SIH-SUS, the hospital admissions database of the Brazilian Public Health System (SUS), which accounts for $80 \%$ of the country's 
Table 1

Influenza vaccine coverage and effectiveness studies in Brazil, 1999 - 2009

\begin{tabular}{|c|c|c|c|c|c|}
\hline Reference & Place & Time & Vaccinated group & $\begin{array}{c}\text { Survey' vaccine } \\
\text { coverage }\end{array}$ & $\begin{array}{c}\text { MOH vaccine } \\
\text { coverage }\end{array}$ \\
\hline Bellei et al., $2007^{4}$ & São Paulo & $2001-2003$ & Health professionals & $19.7 \%$ & $-{ }^{a}$ \\
\hline Bellei et al., $2007^{5}$ & São Paulo & $2001-2003$ & $\begin{array}{l}\text { Health professionals and } \\
\text { transplant patients }\end{array}$ & $19.7 \%$ and $0 \%$ & $-{ }^{-a}$ \\
\hline Cabral, $2006^{7}$ & $\begin{array}{l}\text { Rio de Janeiro, two } \\
\text { communities }\end{array}$ & 2004 & Population $>60$ years of age & $50.2 \%$ and $38.3 \%$ & $\begin{array}{l}75.7 \% \text { (Municipality } \\
\text { of Rio de Janeiro) }\end{array}$ \\
\hline Cesar et al., $2008^{9}$ & $\begin{array}{l}\text { Municipalities of } \\
\text { Caracol and Garrafão } \\
\text { do Norte }\end{array}$ & 2005 & Population $>60$ years of age & $80.2 \%$ and $88.1 \%$ & $87.5 \%$ and $99.9 \%$ \\
\hline $\begin{array}{l}\text { Donalisio et al., } \\
2006^{13}\end{array}$ & Botucatu & 2003 & Population $>60$ years of age & $63.2 \%$ & $70 \%$ \\
\hline $\begin{array}{l}\text { Francisco et al., } \\
2006^{16}\end{array}$ & $\begin{array}{l}6 \text { municipalities in the } \\
\text { State of São Paulo }\end{array}$ & $2001-2002$ & Population $>60$ years of age & $66 \%$ & $\begin{array}{l}66.3 \%(2001) \text { and } \\
62 \%(2002)\end{array}$ \\
\hline $\begin{array}{l}\text { Francisco et al., } \\
2006^{17}\end{array}$ & $\begin{array}{l}6 \text { municipalities in the } \\
\text { State of São Paulo }\end{array}$ & $2001-2002$ & Population $>60$ years of age & $\begin{array}{c}66.3 \%(2001) \text { and } \\
62 \%(2002)\end{array}$ & $64.3 \%$ \\
\hline $\begin{array}{l}\text { Francisco et al., } \\
2006^{20}\end{array}$ & $\begin{array}{l}5 \text { municipalities in the } \\
\text { State of São Paulo }\end{array}$ & $2001-2002$ & Population $>60$ years of age & $\begin{array}{l}66.9 \% \text { and } 67.6 \% \text { in } \\
\text { the different sample } \\
\text { strata }\end{array}$ & $64.3 \%$ \\
\hline Geronutti et al., $2008^{22}$ & Botucatu & 2006 & $\begin{array}{l}\text { Population }>60 \text { years of age, } \\
\text { attending a primary care clinic }\end{array}$ & $83.8 \%$ & $62.2 \%$ \\
\hline Gutierrez et al., $2001^{23}$ & São Paulo & 1999 & $\begin{array}{l}\text { Population }>60 \text { years of age, } \\
\text { attending a reference hospital }\end{array}$ & $70.1 \%$ & $79.3 \%$ \\
\hline Lima-Costa, $2008^{24}$ & Belo Horizonte & 2003 & Population $>60$ years of age & $66.3 \%$ & $85.5 \%$ \\
\hline Machado et al., $2005^{25}$ & São Paulo & $2001-2002$ & $\begin{array}{c}\text { Bone marrow transplant } \\
\text { patients }\end{array}$ & $44.2 \%$ & $-{ }^{a}$ \\
\hline Santos et al., $2009^{30}$ & Porto Alegre & 2006 & $\begin{array}{l}\text { Population }>60 \text { years of age, } \\
\text { attending a reference hospital }\end{array}$ & $76.5 \%$ & $72.5 \%$ \\
\hline $\begin{array}{l}\text { Takayanagi et al., } \\
2007^{33}\end{array}$ & São Paulo & 2002 & Health professionals & $34.4 \%$ & $-a$ \\
\hline
\end{tabular}

a - The Ministry of Heath does not provide data on influenza vaccine coverage for health professionals or immune-deficient patients, for alleged lack of denominator for calculus.

hospital admissions. The overall pattern of influenza-related hospital admissions is similar to that of mortality studies. Some studies show a reduction in hospital admissions, more pronounced in Southern states, while others point to an increase in influenza-related hospitalizations, especially in North and Northeastern states.

Seasonality: influenza seasonality has been addressed by the analysis of mortality and morbidity data, and also of laboratorial surveillance data. When morbidity and mortality data are analyzed together, a marked peak of influenza-related mortality and morbidity in South and Southeastern states in late autumn/early winter months become evident, while seasonality is not so evident in North and Northeastern regions ${ }^{28,29,30}$. One study concluded that influenza activity in the North peaks earlier in the year, and heads South as it gradually shifts to the winter months, a movement that has been described by authors as a "seasonal southward traveling wave, originating in equatorial and low-populated regions in
March-April, and moving towards temperate and highly populous regions in a three-month period".

Studies using an individualized design: only two of the recovered studies analyzed the Brazilian vaccination strategy using an individuallybased design ${ }^{23,25}$. A cross-sectional study conducted early in the course of the initiative in 2000, targeted the elderly clientele of the largest university hospital complex in the country. Patients that came to receive the influenza vaccine were invited to participate, and asked if they had been vaccinated against influenza the year before and whether they had presented episodes of influenza-like illness (ILI) during the year. The proportion that indicated at least one ILI episode was $45 \%$ among those vaccinated, and $48 \%$ among the non-vaccinated $(p=0.69)$. The mean number of ILI episodes reported during the year was 1.5 among vaccinated subjects and 2.25 among non-vaccinated $(p=0.019)^{23}$. Another study analyzed the effectiveness of the vaccination of transplant patients ${ }^{25}$. 
Table 2

Ecological studies addressing influenza vaccine effectiveness and influenza seasonality, Brazil, 1999 - 2009

\begin{tabular}{|c|c|c|c|c|}
\hline Reference & Place & Time & Outcome & Main findings \\
\hline Alonso et al., $2007^{1}$ & Brazil & $1979-2001$ & $\begin{array}{l}\text { Pneumonia and influenza monthly } \\
\text { mortality rates for each Brazilian } \\
\text { state }\end{array}$ & $\begin{array}{l}\text { Seasonality most pronounced } \\
\text { in Southern states; a seasonal } \\
\text { southward wave was identified }\end{array}$ \\
\hline Antunes et al., $2007^{2}$ & $\begin{array}{l}\text { Municipality of Sao } \\
\text { Paulo }\end{array}$ & $\begin{array}{l}2 \text { periods: } \\
1993 \text { - } 1997 \text { and } \\
1998-2002 \\
\end{array}$ & $\begin{array}{l}\text { Pneumonia and influenza } \\
\text { mortality rates among }>65 \mathrm{y}\end{array}$ & $\begin{array}{l}26.2 \% \text { reduction in pneumonia } \\
\text { and influenza mortality rates }\end{array}$ \\
\hline Barbosa, $2006^{3}$ & $\begin{array}{l}\text { Municipality of Sao } \\
\text { Paulo }\end{array}$ & $1991-2004$ & $\begin{array}{l}\text { Pneumonia and influenza } \\
\text { mortality rates among }>60 \mathrm{y}\end{array}$ & $\begin{array}{l}\text { Increasing pneumonia and } \\
\text { influenza mortality rates, from } \\
2001 \text { to } 2004\end{array}$ \\
\hline Brondi et al., $2000^{6}$ & Brazil & $1998-2000$ & $\begin{array}{l}\text { Pneumonia and influenza hospital } \\
\text { admissions rates among }>60 \mathrm{y}\end{array}$ & $\begin{array}{l}\text { Reduction in peaks of excess } \\
\text { mortality in Southern states. }\end{array}$ \\
\hline Campagna et al., $2009^{8}$ & Brazil & $1992-2005$ & $\begin{array}{l}\text { Mortality rates for influenza } \\
\text { related causes among }>60 y\end{array}$ & $\begin{array}{l}\text { Increase in mortality rates. } \\
\text { Decrease of the amplitude of } \\
\text { peaks in Southern states. }\end{array}$ \\
\hline Daufenbach et al., $2009^{11}$ & Brazil & $1992-2006$ & $\begin{array}{l}\text { Hospital admissions rates for } \\
\text { influenza related causes among } \\
>60 \mathrm{y}\end{array}$ & $\begin{array}{l}\text { Reduction in rates, most } \\
\text { pronounced in Southern states }\end{array}$ \\
\hline Donalisio et al., $2006^{12}$ & State of São Paulo & $1980-2004$ & $\begin{array}{l}\text { Mortality rates for influenza } \\
\text { related causes among }>60 \mathrm{y}\end{array}$ & $\begin{array}{l}\text { Increase in mortality rates after } \\
2002\end{array}$ \\
\hline Façanha, $2005^{14}$ & $\begin{array}{l}\text { Municipality of } \\
\text { Fortaleza }\end{array}$ & $1992-2003$ & $\begin{array}{l}\text { Hospital admissions and mortality } \\
\text { rates for respiratory and heart } \\
\text { diseases among }>60 \mathrm{y}\end{array}$ & $\begin{array}{l}\text { No change in rates after the } \\
\text { introduction of vaccine }\end{array}$ \\
\hline Ferrer et al., $2008^{15}$ & State of Parana & $1995-2005$ & $\begin{array}{l}\text { Hospital admissions rates for } \\
\text { respiratory diseases among }>60 \mathrm{y}\end{array}$ & $\begin{array}{l}\text { Decreasing tendency in } \\
\text { hospitalizations in both genders }\end{array}$ \\
\hline Francisco et al., $2005^{18}$ & State of Sao Paulo & $1980-2000$ & $\begin{array}{l}\text { Mortality rates for influenza } \\
\text { related causes among }>60 \mathrm{y}\end{array}$ & Reduction in mortality rates \\
\hline Francisco et al., $2004^{19}$ & State of Sao Paulo & $1995-2002$ & $\begin{array}{l}\text { Hospital admissions rates for } \\
\text { respiratory diseases among }>60 \mathrm{y}\end{array}$ & $\begin{array}{l}\text { Reduction in peaks of } \\
\text { hospitalizations rates }\end{array}$ \\
\hline Freitas, $2004^{21}$ & Brazil & $1996-2001$ & $\begin{array}{l}\text { Mortality rates for influenza } \\
\text { related causes among }>60 y\end{array}$ & $\begin{array}{l}\text { Reduction in mortality rates } \\
\text { in Southern, Southeastern and } \\
\text { Central states }\end{array}$ \\
\hline Mansur et al., $2009^{26}$ & $\begin{array}{l}\text { Metropolitan Region } \\
\text { of Sao Paulo }\end{array}$ & $1980-2006$ & $\begin{array}{l}\text { Mortality rates for ischemic heart } \\
\text { disease }\end{array}$ & $\begin{array}{l}\text { Significant reduction in mortality } \\
\text { rates }\end{array}$ \\
\hline Mello et al., $2009^{27}$ & $\begin{array}{l}\text { Cities of Belem and } \\
\text { Sao Paulo }\end{array}$ & $1999-2007$ & Influenza virus isolates & $\begin{array}{l}\text { Different scenarios using } \\
\text { Northern or Southern hemisphere } \\
\text { vaccine }\end{array}$ \\
\hline Moura et al., $2009^{28}$ & City of Fortaleza & 2001- 2007 & $\begin{array}{l}\text { Laboratory-based surveillance } \\
\text { data }\end{array}$ & $\begin{array}{l}\text { Peak incidence coincides with } \\
\text { rainy season }\end{array}$ \\
\hline Silvestre, $2002^{31}$ & Brazil & $1999-2001$ & $\begin{array}{l}\text { Hospital admissions for influenza } \\
\text { related causes among > } 60 \mathrm{y}\end{array}$ & $\begin{array}{l}\text { Reduction in total number of } \\
\text { hospital admissions for influenza } \\
\text { related causes }\end{array}$ \\
\hline
\end{tabular}

Finally, we included one review article, published in 2005, which addressed part of the issues we intend to discuss in the present paper, when the number of published papers on these issues was much smaller ${ }^{10}$.

\section{DISCUSSION}

A number of factors might influence the effectiveness of an influenza vaccination strategy. Among them, we may cite vaccine coverage, vaccine "match", and the methodological issues related to the way effectiveness itself is defined and measured.

Concerning vaccine coverage, the Brazilian $\mathrm{MOH}$ administrative data shows coverage above the $70 \%$ target in all years but one since the beginning of the initiative. According to $\mathrm{MOH}$, coverage tends to be higher in North and Northeastern states, and lower in the other regions of the country. Independent survey data cannot be directly compared with national figures, as they usually address smaller geographic units, 
or just the clientele of some outpatient clinics. In spite of the differences in coverage between survey and $\mathrm{MOH}$ data, the former seem to confirm the latter. Surveys have observed coverage typically above $60 \%$, higher in the Northeast and lower in South/Southeastern states.

Another factor that might influence vaccine effectiveness is the extent to which vaccine viral subtypes components match the influenza virus circulating in the population during the same season. Published data on laboratory surveillance of the influenza virus in Brazil are quite limited. In fact, only one paper in our review addressed vaccine match. Using data on viral isolates from two of the influenza national reference laboratories, located in the Amazon region (Belém) and in the Southeastern region (São Paulo), the authors discuss different scenarios that would increase effectiveness of national influenza vaccine campaigns. Viral subtypes that have circulated in Brazil show a similar match with both Northern and Southern hemisphere vaccine composition. According to the study, the use of the Southern hemisphere formulation earlier than currently scheduled (in January) or the use of the Northern hemisphere formulation would both increase the campaign's success ${ }^{27}$.

As presented before, only two studies used individually-based study designs to evaluate influenza vaccine campaigns in Brazil. The first one found a significant difference in the mean number of reported ILI episodes between the vaccinated and the non-vaccinated ${ }^{13}$. The other study evaluated the effectiveness of the influenza vaccine in bone marrow transplant recipients, using a laboratory which confirmed influenza as the outcome variable. Vaccine effectiveness was estimated at $80 \%{ }^{25}$. Morbidity and mortality ecological studies addressing the effectiveness of influenza vaccine campaigns have produced conflicting results. One study failed to demonstrate the effect of the vaccination in hospital admissions and mortality due to influenza-related causes,,${ }^{14}$ another found a $26 \%$ reduction in mortality rates due to influenza and pneumonia, ${ }^{2}$ and three studies point to an increase in influenza-related mortality rates ${ }^{3,8,12}$. Of the six studies analyzing hospital admissions, five found modest reductions in rates or number of hospitalizations, ${ }^{6,11,15,19,31}$ and the previously cited one showed no effect of the vaccination ${ }^{14}$. A large part of this apparent conflict might be explained by the differences in the time frames that were compared, in the geographic regions studied, in the presence or absence of rate standardization, and also in the outcome variables defined. As laboratory diagnosis of influenza is not routinely carried out, the majority of ecological studies use the category of influenzarelated morbidity and mortality causes as a proxy variable. Definitions of influenza-related causes are not standardized, and the different studies have used more or less inclusive definitions. In the particular case of Brazil, another factor that might have influenced mortality studies is the increasing coverage of the National Mortality Statistics System (SIM) and its ongoing improvement of information into the causes of death, with a marked reduction in the proportion of ill-defined mortality causes. This reduction is more pronounced in the less developed regions of the country, the North and Northeast, and might be held responsible for the increase in specified death causes, such as the ones related to influenza. One study showed a significant reduction in ischemic heart disease mortality, when compared to mortality due to cerebrovascular disease and external causes ${ }^{26}$.

In fact, mortality reduction benefits as a result of influenza vaccination are the subject of intense debate. The use of non-specific endpoints and the attribution of a large proportion of winter deaths to influenza have been deemed responsible for exaggerating the benefits of vaccination ${ }^{32}$. Nichol postulates that ecological studies on influenza mortality often assume that the ratio of excess deaths/winter-time deaths is approximately equal to the ratio of influenza-associated deaths/influenza season deaths. By doing so, most studies underestimate the numerator and overestimate the denominator, and produce false estimates of effectiveness ${ }^{29}$.

Besides the non-specific endpoints, ecological studies on influenzarelated morbidity and mortality use average measures that attribute to individuals characteristics of the group, and show associations that might not be valid at an individual level, the so-called ecological fallacy.

An additional factor that has influenced the Brazilian ecological studies is the distinct pattern of influenza seasonality in the country. Using mortality data, ${ }^{1}$ ALONSO et al. have demonstrated that seasonal pattern of influenza-related mortality is different as one moves from Northern to Southern Brazil. Influenza-related mortality peaks occur earlier in the year in the equatorial regions of Brazil, and later as one moves southwards. As influenza vaccine campaigns are scheduled in late April/ early March every year, they have been held after influenza peak season in Northern and most Northeastern Brazilian states, which might have reduced the effectiveness of vaccine campaigns and influenced the results of ecological studies. In fact, all studies suggest no reduction in influenza-related mortality and hospital admissions in Northern and Northeastern Brazilian states following influenza vaccine campaigns. National results have probably been influenced by these regions' ones, reducing the campaign's expected benefits. Paradoxically, vaccine coverage has been higher in the regions where less benefit would be expected, due to the scheduling of the campaigns.

The only review article included in the present selection discussed the caveats of influenza vaccination of the elderly in Brazil ${ }^{10}$. The authors recognize the paucity of data on influenza burden the country, especially for Northern regions, where influenza seasonality is not so evident, and also the limited number of studies on the impact of vaccination campaigns. Considering that "no reduction in disease burden is observed in all Brazilian regions", they question if the current vaccine schedule is justifiable, and advocate for the improvement of influenza surveillance in Brazil.

Our systematic review on the effectiveness of influenza vaccine mass campaigns conducted in Brazil since 1999 has provided evidence that influenza vaccine coverage among the elderly is high, although not so high as presented by the official figures. Estimates on effectiveness are scarce. The majority of them come from ecological studies that show a modest reduction in mortality and hospital admissions due to influenza-related causes. Such reduction is not evident in the North and Northeastern states of Brazil, a finding that is probably related to the different seasonal pattern of influenza in equatorial and tropical regions. A change in vaccination schedule, with the anticipation of campaigns in North and Northeastern regions of the country, should be seriously considered, using either the Southern or Northern hemisphere vaccine. Most studies did not quantify the observed tendencies in mortality and hospital admissions.

In 2010, Brazil is conducting one of the largest influenza vaccine campaigns ever and Brazilian epidemiologists still owe society betterdesigned studies to address the effectiveness of influenza vaccine campaigns. 


\section{RESUMO}

\section{Efetividade da política brasileira de vacinação contra influenza, uma revisão sistemática}

Desde 1999 o Brasil realiza campanhas anuais de vacinação contra influenza. A vacinação é gratuita, e tem como grupos alvo os idosos, os profissionais de saúde e os pacientes com comprometimento imunitário. Nós realizamos uma revisão sistemática da literatura, com o propósito de avaliar a efetividade desta iniciativa. Foram usadas as palavras chave influenza, vacina, Brasil e efetividade, para a busca nas bases de dados mais relevantes. Trinta e um estudos se encaixaram nos nossos critérios de inclusão e exclusão. A cobertura vacinal nos idosos é alta, porém não tão alta como apresentado nos dados oficiais. Estimativas de efetividade são escassas. A maioria delas vem de estudos ecológicos, que demonstram um modesto efeito na redução da mortalidade e internações hospitalares por causas relacionadas à influenza. Esta redução não se evidencia nos estados do Norte e Nordeste do Brasil, achado que provavelmente relaciona-se ao padrão distinto de sazonalidade da influenza nas regiões equatoriais e tropicais. Os epidemiologistas brasileiros ainda devem à sociedade estudos com desenhos mais adequados à análise da efetividade das campanhas de vacinação contra influenza.

\section{REFERENCES}

1. Alonso WJ, Viboud C, Simonsen L, Hirano EW, Daufenbach LZ, Miller M A. Seasonality of influenza in Brazil: a traveling wave from the Amazon to the subtropics. Am J Epidemiol. 2007;165:1434-42.

2. Antunes JL, Waldman EA, Borrell C, Paiva TM. Effectiveness of influenza vaccination and its impact on health inequalities. Int J Epidemiol. 2007;36:1319-26.

3. Barbosa H. Mortalidade por pneumonia e influenza na população de 60 anos e mais no município de São Paulo entre 1991 a 2004. [dissertação]. São Paulo: Secretaria de Estado da Saúde, Pós-Graduação em Ciências da Coordenadoria de Controle de Doenças; 2006

4. Bellei NC, Carraro E, Perosa AH, Benfica D, Granato CF. Influenza and rhinovirus infections among health-care workers. Respirology. 2007;12:100-3.

5. Bellei NC, Carraro E, Perosa AH, Granato CF. Patterns of influenza infections among different risk groups in Brazil. Braz J Infect Dis. 2007;11:399-402.

6. Brondi LM, Barbosa J. Vacina contra influenza: experiencia en Brasil. In: Resúmenes de $1012^{\circ}$ Congresso Latinoamericano de Pediatria-taller sobre imunizaciones, 2000. Montevideo; 2000. p. 26-7.

7. Cabral M. A campanha nacional de vacinação de idosos como estratégia de entrada do Programa de Saúde da Família em área programática de saúde do município do Rio de Janeiro - RJ: planejamento, implementação e execução. Cad Saúde Coletiva. 2006;14:425-34.

8. Campagna AS, Dourado I, Duarte EC, Daufenbach LZ. Mortalidade por causas relacionadas à influenza em idosos no Brasil, 1992 a 2005. Epidemiol Serv Saúde. 2009;18:209-18.

9. Cesar JA, Oliveira-Filho JA, Bess G, Cegielka R, Machado J, Gonçalves TS, et al. Perfil dos idosos residentes em dois municípios pobres das regiões Norte e Nordeste do Brasil: resultados de estudo transversal de base populacional. Cad Saúde Pública. 2008;24:1835-45.

10. Cunha SS, Camacho LA, Santos AC, Dourado I. Influenza vaccination in Brazil: rationale and caveats. Rev Saúde Pública. 2005;39:29-36.
11. Daufenbach LZ, Carmo EH, Duarte EC, Campagna AS, Teles CA. Morbidade hospitalar por causas relacionadas à influenza em idosos no Brasil, 1992 a 2006. Epidemiol Serv Saúde. 2009;18:29-44.

12. Donalisio MR, Francisco PM, Latorre MR. Tendência da mortalidade por doenças respiratórias em idosos antes e depois das campanhas de vacinação contra influenza no Estado de São Paulo, 1980 a 2004. Rev Bras Epidemiol. 2006;9:32-41

13. Donalisio MR, Ruiz T, Cordeiro R. Factors associated with influenza vaccination among elderly persons in Southeastern Brazil. Rev Saúde Pública. 2006;40:115-9.

14. Façanha, M. Influenza vaccination of individuals over the age of 60: impact on hospital admissions and deaths from respiratory and circulatory diseases in Fortaleza, Brazil. J Bras Pneumol. 2005;31:415-20.

15. Ferrer AL, Marcon SS, Santana RG. Hospital morbidity among elderly patients, before and after influenza vaccination in the state of Paraná. Rev Lat Am Enfermagem. 2008;16:832-7.

16. Francisco PM, Donalisio MR, Barros MB, Cesar CL, Carandina L, Goldbaum M. Fatores associados à vacinação contra a influenza em idosos. Rev Panam Salud Publica. 2006;19:259-64.

17. Francisco PM, Donalisio MR, Barros MB, Cesar CL, Carandina L, Goldbaum M. Fatores associados à doença pulmonar em idosos. Rev Saúde Pública. 2006;40:428-35

18. Francisco PM, Donalisio MR, Latorre MR. Impact of influenza vaccination on mortality by respiratory diseases among Brazilian elderly persons. Rev Saúde Pública. 2005;39:7581.

19. Francisco PM, Donalisio MR, Lattorre MR. Internações por doenças respiratórias em idosos e a intervenção vacinal contra influenza no Estado de São Paulo. Rev Bras Epidemiol. 2004,7:220-7.

20. Francisco PMSB, Donalisio MR, Barros MBA, César CLG, Carandina L, Goldbaum M Vacinação contra influenza em idosos por área de residência: prevalência e fatores associados. Rev Bras Epidemiol. 2006; 9:162-71.

21. Freitas MPD. Estudo temporal da mortalidade de idosos por doenças respiratórias associadas à influenza no Brasil, 1996-2001. [dissertação]. Belo Horizonte: Universidade Federal de Minas Gerais; 2004.

22. Geronutti DA, Molina AC, Lima SA. Vacinação de idosos contra a influenza em um centro de saúde escola do interior do estado de São Paulo. Texto Contexto Enferm. 2008; 17:336-41.

23. Gutierrez EB, Li H, Santos AC, Lopes MH. Effectiveness of influenza vaccination in elderly outpatients in Sao Paulo city, Brazil. Rev Inst Med Trop Sao Paulo. 2001;43:317-20.

24. Lima-Costa M. Factores associados à vacinação contra gripe em idosos na região metropolitana de Belo Horizonte. Rev Saúde Pública. 2008;42:100-7.

25. Machado CM, Cardoso MR, Rocha IF, Boas LS, Dulley FL, Panutti CS. The benefit of influenza vaccination after bone marrow transplantation. Bone Marrow Transplant. 2005;36:897-900.

26. Mansur AP, Favarato D, Ramires JAF. Vacina contra o vírus da influenza e mortalidade por doenças cardiovasculares na cidade de São Paulo. Arq Bras Cardiol. 2009;93:395-9.

27. Mello WA, Paiva TM, Ishida MA, Benega MA, Santos MC, Vibboud C, et al. The dilemma of influenza vaccine recommendations when applied to the tropics: the Brazilian case examined under alternative scenarios. PLoS One. 2009;4(4):e5095.

28. Moura FE, Perdigão AC, Siqueira MM. Seasonality of influenza in the tropics: a distinct pattern in northeastern Brazil. Am J Trop Med Hyg. 2009;81:180-3.

29. Nichol KL. Challenges in evaluating influenza vaccine effectiveness and the mortality benefits controversy. Vaccine. 2009;27:6305-11. 
30. Santos BRL, Creutzberg M, Cardoso RFML, Lima SF, Gustavo AS, Viegas K, et al. Situação vacinal e associação com a qualidade de vida, a funcionalidade e a motivação para o autocuidado em idosos. Rev Bras Epidemiol. 2009;12:533-40.

31. Silvestre, JA. O impacto da vacinação antiifluenza na população idosa. In: Freitas EV, Py L, Neri AL, Cançado FA, Gorzoni ML, Rocha SM, editores. Tratado de geriatria e gerontologia. Rio de Janeiro: Guanabara Koogan, 2002. p. 569-73.

32. Simonsen L, Taylor RJ, Viboud C, Miller MA, Jackson LA. Mortality benefits of influenza vaccination in elderly people: an ongoing controversy. Lancet Infect Dis. 2007;7:658 66 .
33. Takayanagi IJ, Cardoso MR, Costa SF, Araya ME, Machado CM. Attitudes of health care workers to influenza vaccination: why are they not vaccinated? Am J Infect Control. 2007;35:56-61

Received: 14 April 2010

Accepted: 5 July 2010 